\title{
Editorial
}

\section{What is next for CLIL Professional Development?}

¿Qué sigue para el desarrollo profesional en AICLE?

O que vem agora para o desenvolvimento profissional em CLIL?

Jermaine S. McDOUGALD

https://orcid.org/o000-0002-2558-5178

Universidad de La Sabana, Colombia

jermaine.mcdougaldı@unisabana.edu.co

To reference this editorial (APA) / Para citar esta editorial (APA) / Para citar este editorial (APA) McDougald, J. (2019). What is next for CLIL professional development? Latin American Journal of Content \& Language Integrated Learning, 12(2), 197-206. https://doi. org/10.5294/laclil.2019.12.2.1 


\section{Introduction}

Professional development (PD) continues to be at the forefront of education and quality learning, as it suggests that teachers need to continuously learn, progress and stay up to date with the latest trends in education. However, this is easier said than done; PD is a requirement, not an option, for both novice and experienced teachers. Yet, professional development for CLIL teachers and practitioners continues to be a challenge for many, considering the diverse ground that needs to be covered (Frigols-Martin, 2011; Vilkancienè \& Rozgiene, 2017). There are formal and informal PD plans for language professionals and for content experts, and generic PD plans that try to combine forces, attempting to bring them all together. Nevertheless, professional development is built on a constant learning process for teachers and practitioners alike (Borko, 2007; Freeman, Reynolds, Toledo, \& Abu-Tineh, 2016). There are numerous forms and types of $\mathrm{PD}$, providing a training solution for almost any scenario. Accordingly, literature has approached PD from different angles, such as strategies, formal and informal training programs, workshops, and diverse educational activities, just to name a few.

In the same fashion, there are both formal and informal PD initiatives that are effective to enhance pedagogical practices, which in turn directly impact the students' success in their learning process. Nevertheless, CLIL Professional Development Programs must consider the teacher as the learner, the context, and the tutor (teacher/practitioner), language, content expertise, along with twenty-first-century competencies and skills, bilingual instructional competences, language teacher competencies and, last but not least, content teacher competence. As there are still many gray areas when it comes to CLIL, PD is of the essence. All in all, there are institutional training plans and individual PD plans that are not aligned, therefore resulting in limited or no progress in the teaching-learning process, leading to unsuccessful CLIL-orientated implementations at educational institutions (Aiello, Di Martino, \& Di Sabato, 2015; Pérez Cañado, 2016a). On the contrary, the following reflections remain, whether or not CLIL, as an approach to education, is the problem or those involved in the implementation are not prepared, especially since there are so many variables at stake. Yet, those "gray areas" must be a priority to effectively training those involved — teachers, 
content experts, practitioners, administrators - who are oftentimes not prepared to take on a CLIL-oriented solution, thereby resulting in successful implementation attempts and negative academic results.

\section{Importance of CLIL Professional Development}

It is often seen that most CLIL teachers are subject content experts who rarely have language qualifications (Nikula, Dalton-Puffer, \& García, 2013) or language professionals who have been required to teach content subjects (e.g., math or science geography) but lack expertise on a particular subject. Therefore, investing in CLIL teachers' language proficiency and CLIL teaching concepts are absolutely mandatory for the implementation of an approach as CLIL (Frigols-Martin, 2011; Pérez-Cañado, 2016). Literature has repeatedly highlighted that CLIL teachers are insecure, as they have deficient language skills themselves to successfully implement CLIL (Bruton, 2011; Murillo-Caicedo, 2016), in many cases, possessing A2 in accordance with the Common European Framework of Reference (CEFR) or barely reaching B1 (CEFR). Yet, most CLIL teachers do not know how to deliver "CLIL-orientated" classes since they are often not aware that the teaching methods and approaches are different and have changed since they were initially licensed as teachers (Tatzl, 2011; Vázquez \& Ellison, 2013). Consequently, the teachers' lack of knowledge on content and language integration has put CLIL teachers on the spotlight, often being criticized for their shortcomings in the classroom. This leads to the conclusion that effective CLIL teacher training programs are highly required across the board and throughout all levels of education, which provide practitioners a fair opportunity to excel in multilingual environments. As such, they become more in touch with CLIL, along with all the resources and strategies that are intertwined with this approach.

\section{Direct relation to the teaching-learning process (Learner)}

It is no secret that learners will not succeed throughout the teaching and learning process if teachers are not properly trained, especially in 
a CLIL-oriented multilingual environment. Since teachers and stakeholders can now become aware of their learners' needs, as a result of PD, they can now provide viable solutions for academic success. Continuous professional development not only equips teachers with a multitude of opportunities, resources, and approaches, but also helps 200 them to become better-qualified professionals that are immersed in achieving success by all means, where they know how to solve problems, overcome obstacles and embrace challenges that arise in multilingual environments.

\section{Empowering teachers through professional development}

PD increases teachers' confidence, and rights, as well as their status in the classroom, thereby encouraging them to be more active participants in their own learning process. This alone goes a long way in establishing certain priorities inside and outside of the classroom. This empowerment sends a clear message to the educational community, where they are valued and respected. Learners are motivated as a result of their "teacher" taking the time to "go back to school" so as to help them become better learners, which, in turn, strengthens communication amongst stakeholders and the desire to achieve the best possible results, based on real context-oriented strategies.

\section{Fosters innovation and creativity in the classroom}

Learners often complain that lessons are boring lack didactics, interaction or even improved methodology, as evidenced in classroom observations and verified through end-of-term evaluations of the teaching staff. However, when visiting classrooms with teachers that have recently completed PD programs, they often bring new energy to the classroom, leading the way with innovation and establishing a clear path for boundless creativity for teaching and learning. Teacher's motivation and commitment levels are high, thereby contributing to academic success. CLIL practitioners now have new ways of interaction, improved communication, and are more sensitive to their learners' needs. 


\section{Setting up a CLIL Professional Program}

There are four (4) key elements, as seen in Figure 1, that stand out and should be considered when planning and/or incorporating CLIL professional development programs. For starters, there should be specific training objectives. These objectives are aligned with the needs of the educational institution and the learners, allowing the teachers to focus their energy on a specific aspect. In that way, institutions can identify one to three instructional priorities and effective instructional practices that the educational institution (EI) wants the teachers to either learn, refine or improve. These priorities should be discussed and/or negotiated with input from teachers, not merely imposed. Then, the same established priorities should be clearly communicated and discussed amongst the stakeholders at all levels, hence, making it much easier for all of those involved to work towards the same priorities, where they can be tracked and evaluated against the desired academic results.

On another note, there are also personalized training plans, which are designed specifically for a teacher. This is very helpful for new teachers just joining the educational institution, or senior teachers that need to be refreshed on a topic. These personalized plans are also continuous and have proven to aid educational institutions in keeping their personnel focused on areas that they need to improve on. Considering that there an array of areas that need attention in order to successfully implement a CLIL orientated solution, teachers have established priorities and are aware of what they need to improve, thereby enhancing their classroom performance and their learners' academic success.

Imposing training on teachers does not always have a positive effect on the overall teaching and learning process. Therefore, it is imperative to decide on a bottom-up us. top-down approach to teacher training. Often, educational institutions decide on training, without consulting with teachers, who are forced to attend a certain course. The outcome leads to demotivated teachers who are unfocused during the training sessions, and most of the dynamics of their classrooms remain the same, which translates into time lost and no return on investment. However, if the training needs are communicated to the teachers and there is dialogue as to what the institution perceives as a need or pri- 
ority and there is a consensus amongst the teachers, the training is oftentimes received better, especially since the "voice" of the teachers are heard and considered. Top-down approaches to professional development are needed as they contemplate short, medium and long terms goals for the educational institution. However, bottom-up training endeavors are mainly decided on by the teacher/professional, where he/she sees the need to improve on aspects of their own teaching practices, leading to improved teacher identity. Both models should be continuous and employed, but there must be effective communication channels as to institutional goals, so that the training is linked, and professional development is not taken for granted.

\section{Figure 1. Professional development practices}

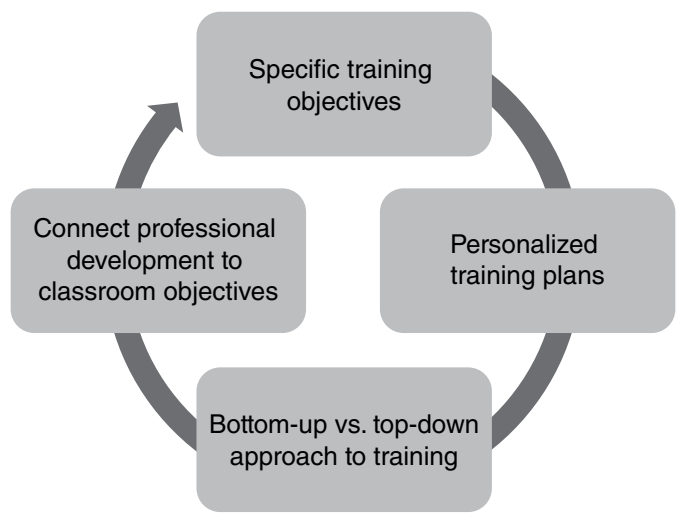

Source: Own elaboration.

Training sessions are usually early morning or late afternoon, always juggling with the classes and academic commitments. In both cases, training is usually disconnected from the teacher's reality and context. Therefore, it is crucial to Connect professional development to classroom objectives and activities. Training does not have to be so standardized (before school or after school) but can take place in the classroom with learners or throughout the school day. There are a few in-house opportunities for training, such as classroom observations, peer-observations, coaching and mentoring, or even spaces during lunchtime in smaller groups organized according to certain topics, spaces to co-create/innovate, think tanks or spaces for teachers to "think-pair-share" on innovative teaching practices. This means that teachers need to be provided with constant feedback on their teaching and they need to 
convert that feedback into formation (positive change-good attitude), developmental opportunities and not just evaluative which often lead to disciplinary (negative change) processes. Teachers need to know what they are doing correctly and what needs to be adjusted, and this alone can go a long way in making a positive impact inside the classroom and a step closer to successful academic achievement in CLIL-oriented classrooms.

\section{In this issue}

The articles in this issue of the Latin American Journal of Content \& Language Integrated Learning (LACLIL, Vol. 12, No. 2, 2019) focus on the competences, professional development, and teacher training in CLIL, as well as the viability of implementing English as a Medium of Instruction (EMI) as a solution in secondary education. Custodio-Espinar (2019) starts the issue by exploring teachers' competences to plan CLIL lessons for bilingual education. The results confirm that education and training in CLIL competencies are needed in order to help guarantee the quality and sustainability of bilingual programs in Spain, where the teacher's competence in CLIL has a direct relation to the students' academic results. Banegas (2019) claims, in his case study on professional development in language-driven CLIL in Argentina, that authenticity, as opposed to language-content integration, is an essential feature of language-driven CLIL. Nevertheless, learners' language proficiency helps define success in the CLIL classroom. The case study also highlights how teacher reflection helps in constructing/developing teacher identity, which is a part of the eco-system of professional development, also considered to be a Bottom-Up approach to professional development.

On another note, EMI continues to be a viable alternative to many educational institutions to better combine language and content. EMI continues to emerge across the globe, making itself known throughout the educational arena, mainly in secondary and higher education environments. Reza Ghorbani (2019) provides some insight regarding a feasibility study into whether EMI would be the best option to partially 
teach Mathematics and Science subjects (MSSs) in secondary education in Iran. The results report EMI as a possible solution to teach content using English, all the while providing key insights for administrators and policymakers to make informed decisions. Furthermore, Santana's (2019) qualitative ethnographic study in Mexico provided a critical analysis between two groups of students - Spanish Native and EMI - in a higher-education communications research course. The author was able to establish that rapport building was much more evident in the EMI course, even though both courses had identical content, materials, etc. The language of delivery proved to make a difference in establishing teacher-student rapport in a bilingual, content-driven environment.

In summary, the articles in this issue have provided new literature to the academic community as to how content and language are being managed across the globe. Both CLIIL and EMI continue to emerge globally making a positive difference in the teaching-learning process. Nevertheless, professional development must stay at the forefront of academic debates, so that all those "gray" areas that exist between the teacher, student, curricula and institutional demands are clearly brought to the surface. Consistency with PD will help to ensure that quality remains a priority in the classroom. As there are an array of possibilities for $\mathrm{PD}$, both formal and informal, using either a top-down or bottom-up approach, practitioners and decision/policymakers need to keep the channel of communication open and direct, so that the training that is planned and conducted actually makes a difference inside the classroom, thereby leading to increased academic results in multilingual environments.

\section{References}

Aiello, J., Di Martino, E., \& Di Sabato, B. (2015). Preparing teachers in Italy for CLIL: Reflections on assessment, language proficiency and willingness to communicate. International Journal of Bilingual Education and Bilingualism, 0050(November), 1-15. http://dx.doi.org/10.1080/13 670050.2015 .1041873

Banegas, D. L. (2019). Teacher professional development in language-driven CLIL: A case study. Latin American Journal of Content \& Language Integrated Learning, 12(2), 242-264. https://doi.org/10.5294/laclil.2019.12.2.3 
Borko, H. (2007). Professional development and teacher learning: mapping the terrain. Educational Researcher, 33(8), 3-15. http://dx.doi. org/10.3102/0013189x033008003

Bruton, A. (2011). Are the differences between CLIL and non-CLIL groups in Andalusia due to CLIL? A reply to Lorenzo, Casal and Moore (2010). Applied Linguistics. http://dx.doi.org/10.1093/applin/amr007

Custodio, M. (2019). Influencing factors on in-service teachers' competence in planning CLIL. Latin American Journal of Content \& Language Integrated Learning, 12(2), 207-241. https://doi.org/10.5294/laclil.2019.12.2.2

Freeman, D., Reynolds, D., Toledo, W., \& Abu-Tineh, A. M. H. (2016). Who provides professional development? A study of professional development in Qatar. Iranian Journal of Language Teaching Research, 4(3), 5-19.

Frigols-Martin, M. J. (2011). The European framework for CLIL teacher education. Language Teaching, 44(3), 401-402. http://dx.doi.org/10.1017/ S0261444811000243

Murillo-Caicedo, A. J. (2016). Coaching for CLIL: A training proposal for nonCLIL content primary teachers in the Principado de Mónaco Bilingual School (Published Master's thesis), Universidad Internacional de La Rioja.

Nikula, T., Dalton-Puffer, C., \& García, A. L. (2013). CLIL classroom discourse: Research from Europe. Journal of Immersion and Content-Based Language Education. http://dx.doi.org/10.1075/jicb.1.1.04nik

Pérez-Cañado, M. L. (2016a). Are teachers ready for CLIL? Evidence from a European study. European Journal of Teacher Education, 39(2), 202-221. http://dx.doi.org/10.1080/02619768.2016.1138104

Pérez-Cañado, M. L. (2016b). Evaluating CLIL Programmes: Instrument design and validation. Pulso, 39, 79-112.

Reza, M. (2019). Feasibility of adopting English as a partial Medium of Instruction for mathematics and science subjects in Iranian senior high schools. Latin American Journal of Content \& Language Integrated Learning, 12(2), 292-320. https://doi.org/10.5294/laclil.2019.12.2.5

Santana, J. del C. (2019). Establishing teacher-student rapport in an English medium instruction class. Latin American Journal of Content \& Language Integrated Learning, 12(2), 265-291. https://doi.org/10.5294/ laclil.2019.12.2.4

Tatzl, D. (2011). English-medium masters' programmes at an Austrian university of applied sciences: Attitudes, experiences and challenges. Journal of English for Academic Purposes, 10(4), 252-270. http://dx.doi. org/10.1016/j.jeap.2011.08.003 
Vázquez, V. P., \& Ellison, M. (2013). Examining teacher roles and competences in (CLIL). Linguarum Arena, 4(CLIL), 65-78.

Vilkancienè, L., \& Rozgienè, I. (2017). CLIL Teacher competences and attitudes. Sustainable Multilingualism, 11(1), 196-218. http://dx.doi. org/10.1515/sm-2017-0019 